\title{
PENGARUH PENGGUNAAN SEMEN SEBAGAI BAHAN STABILISASI PADA TANAH LEMPUNG DAERAH LAMBUNG BUKIT TERHADAP NILAI CBR TANAH
}

\author{
Andriani $^{1}$, Rina Yuliet $^{2}$, Franky Leo Fernandez ${ }^{3}$
}

\begin{abstract}
ABSTRAK
Tanah merupakan material yang sangat berpengaruh dalam suatu pekerjaan konstruksi, karena suatu daerah tidak akan memiliki sifat tanah yang sama dengan daerah lainnya. Sebagian besar wilayah di Indonesia khususnya Kota Padang berada pada tanah lunak. Dua pokok masalah pada tanah lunak adalah penurunan yang besar dan daya dukung tanah yang kecil. Salah satu usaha perbaikan tanah yang akan diteliti adalah stabilisasi tanah dengan menggunakan bahan aditif yaitu Portland Cement Type I. Stabilisasi adalah memperbaiki sifat fisik dan mekanik tanah sehingga memenuhi persyaratan teknis tertentu. Tujuan penelitian ini untuk membandingkan nilai CBR tanah lempung sebelum dan setelah distabilisasi dengan penambahan Portland Cement Type I. Tanah yang akan distabilisasi adalah tanah lempung yang berasal dari daerah Lambung Bukik, Padang, dengan nilai CBR $<10 \%$. Penelitian meliputi sifat fisik dan mekanik tanah yaitu parameter pemadatan dan uji CBR. Pengujian ini berpedoman pada ASTM untuk setiap pengujian. Variasi penambahan semen adalah $5 \%, 10 \%, 15 \%$, dan $20 \%$ dari berat tanah kering. Pemeraman dilakukan sebelum dilakukan uji CBR, dengan waktu pemeraman selama 3 hari pada kondisi kadar air optimum. Hasil dari penelitian ini menunjukkan bahwa nilai maksimum CBR tanah lempung terdapat pada kadar penambahan semen sebanyak $20 \%$ dengan $\gamma_{\text {dry }}$ maksimum $1.351 \mathrm{gr} / \mathrm{cm}^{3}$, kadar air optimum 32.9\%, dan nilai CBR $64.138 \%$ dengan waktu pemeraman 3 hari.
\end{abstract}

Kata Kunci : tanah lempung, stabilisasi tanah, portland cement type I, CBR.

\section{PENDAHULUAN}

Tanah didefisinikan sebagai material yang terdiri dari agregat (butiran) mineral-mineral padat yang tidak tersementasi (terikat secara kimia) satu sama lain dan dari bahan-bahan organik yang telah melapuk (yang berpartikel padat) disertai dengan zat cair dan gas yang mengisi ruang-ruang kosong di antara partikel-partikel padat tersebut. Tanah berguna sebagai bahan bangunan pada berbagai macam pekerjaan teknik sipil. Disamping itu tanah berfungsi juga sebagai pendukung pondasi dari bangunan. Jadi seorang ahli teknik sipil harus juga mempelajari sifat-sifat dasar dari tanah,seperti asal usulnya, penyebaran ukuran butiran, kemampuan mengalirkan air,sifat pemampatan bila dibebani (compressibility), kekuatan geser, kapasitas daya dukung terhadap beban, dan lain-lain (Braja M. Das, 1988).

Umumnya sebagian besar wilayah Indonesia ini diliputi oleh tanah lempung dengan pengembangan yang cukup besar (plastisitas tinggi), volumenya akan berubah (mengembang) bila kadar air bertambah (berubah). Volumenya akan membesar dalam kondisi basah dan akan menyusut bila dalam kondisi kering. Sifat inilah yang menyebabkan kerusakan pada konstruksi-kontruksi bangunan, khususnya pada bagian pondasi yang merupakan konstruksi pada bangunan yang menghubungkan bangunan dengan tanah. Pondasi inilah yang berfungsi untuk mendistribusikan beban bangunan langsung ke tanah. Kerusakan tersebut disebabkan oleh adanya penambahan volume tanah yg disebabkan bertambahnya volume air tanah yang biasanya terjadi hanya disatu titik pada bagian pondasi.

\footnotetext{
${ }^{1}$ Dosen Jurusan Teknik Sipil Fakultas Teknik Universitas Andalas

${ }^{2}$ Dosen Jurusan Teknik Sipil Fakultas Teknik Universitas Andalas

${ }^{3}$ Staf Teknis Pusat Studi Bencana Universitas Andalas
} 
Stabilisasi tanah dapat dilakukan secara mekanis maupun menggunakan bahan-bahan aditif (zat kimia). Secara mekanis stabilisasi tanah dilakukan dengan mengatur gradasi butiran tanah kemudian dilakukan proses pemadatan, sedangkan stabillisasi yang menggunakan bahan aditif dapat dilakukan dengan menambah bahan aditif kemudian dilakukan pemadatan.

Pada penelitian ini digunakan Semen Portland Tipe I sebagai bahan stabilisasi dan melihat seberapa besar pengaruh campuran semen terhadap daya dukung tanah lempung yang telah distabilisasi. Pemilihan semen sebagai bahan tambahan stabilisasi karena semen relatif mudah diperoleh di kota Padang.

Adapun tujuan dari penelitian yang dilakukan ini adalah :

- Mengetahui sifat fisik dan mekanik jenis tanah butir halus dari daerah Lambung Bukit, Padang, Sumatera Barat

- Mengetahui Pengaruh semen terhadap tanah lempung, sehingga dapat diketahui nilai CBR tanah sebelum dan setelah distabilisasi dengan semen, yaitu dengan cara mencampur tanah lempung dengan semen pada berbagai variasi kadar semen yaitu dengan presentase campuran sebesar 5\%,10\%, 15\%, 20\% dan lama pemeraman 3 hari, dengan tujuan agar dapat mengetahui persentase kadar semen optimum.

Manfaat dari penelitian yang dilakukan adalah :

- Memperoleh pengetahuan mengenai pengaruh yang ditimbulkan oleh penambahan variasi kadar semen terhadap tanah lempung.

- Diharapkan dapat dijadikan sebagai acuan dalam perancangan stabilisasi tanah

\section{DASAR TEORI}

\subsection{Tanah}

Dalam pengertian teknik secara umum, tanah didefinisikan sebagai himpunan mineral, bahan organik dan endapan-endapan yang relatif lepas (loose), yang terletak diatas batuan dasar (bedrock) (Hary Christady Hardiyatmo, 2006). Sedang Braja M. Das (1988) mendefinisikan tanah sebagai bahan yang terdiri dari agregat (butiran) mineral-mineral padat yang tidak tersementasi (terikat secara kimia) antara satu sama lain dari bahan-bahan organik yang telah melapuk (yang berpartikel padat) disertai dengan zat cair dan gas yang mengisi ruang-ruang kosong diantara partikel-partikel padat tersebut. Batasan berat jenis untuk beberapa jenis tanah dapat dilihat pada Tabel 1. Sedangkan untuk hubungan antara indeks plastisitas dan jenis tanah dapat dilihat pada Tabel 2.

Tabel 1. Batasan Berat Jenis untuk Beberapa Jenis Tanah

\begin{tabular}{|l|c|}
\hline \multicolumn{1}{|c|}{ Jenis Tanah } & Batas \\
\cline { 1 - 1 } Pasir & $2,65-2,68$ \\
\hline Kerikil & $2,62-2,68$ \\
\hline Lanau Organik & $2,58-2,65$ \\
\hline Lempung Organik & $2,68-2,75$ \\
\hline Lempung Anorganik & 1,37 \\
\hline Humus & $1,25-1,80$ \\
\hline Gambut
\end{tabular}

Sumber : Hary Christady Hardiyatmo, 2002, Mekanika Tanah 1, hal. 5 
Tabel 2. Hubungan Antara Indeks Plastisitas dan Jenis Tanah

\begin{tabular}{|l|c|c|}
\hline \multicolumn{1}{|c|}{ Jenis Tanah } & Keterangan & $\begin{array}{c}\text { Tingkat } \\
\text { Plastisitas }\end{array}$ \\
\hline Pasir & IP $=0$ & Tidak plastis \\
\hline Lanau & $0<\mathrm{IP} \leq 7$ & $\begin{array}{c}\text { Plastisitas } \\
\text { rendah }\end{array}$ \\
\hline Lempung Berlanau & $7<\mathrm{IP} \leq 17$ & $\begin{array}{c}\text { Plastisitas } \\
\text { sedang }\end{array}$ \\
\hline Lempung & $\mathrm{IP}>17$ & $\begin{array}{c}\text { Plastisitas } \\
\text { tinggi }\end{array}$ \\
\hline
\end{tabular}

Sumber : Braja M. Das, 1985

\section{Tanah Lempung}

Tanah lempung merupakan agregat partikel-partikel berukuran mikroskopik dan submikroskopik yang berasal dari pembusukan kimiawi unsur-unsur penyusun batuan, dan bersifat plastis dalam selang kadar air sedang sampai luas. Menurut Terzaghi Dalam keadaan kering sangat keras, dan tak mudah terkelupas hanya dengan jari tangan. Permeabilitas lempung sangat rendah (Das, 1995)

Partikel-partikel mineral dari lempung merupakan sumber utama dari kohesi di dalam tanah yang kohesif (Bowles, 1991). Tanah lempung merupakan tanah yang berukuran mikroskopis sampai dengan sub mikroskopis yang berasal dari pelapukan unsur-unsur kimiawi penyusun batuan, tanah lempung sangat keras dalam keadaan kering dan bersifat plastis pada kadar air sedang. Pada kadar air lebih tinggi lempung bersifat lengket (kohesif) dan sangat lunak (Das, 1995). Menurut Chen (1975) mineral lempung terdiri dari 3 komponen utama yaitu montmorillonite, illite, dan kaolinite.

\section{Kaolinite}

Umumnya tidak ekspansif karena adanya ikatan hidrogen yang pada kondisi tertentu partikel kaolinite mungkin terbentuk oleh lebih dari seratus tumpukan yang sukar dipisahkan, sehingga mineral ini stabil dan air tidak dapat masuk diantara lempengannya (tidak terjadi pengembangan dan penyusutan pada sel satuannya). Gambar susunan atom kaolinite dapat dilihat pada Gambar 1.

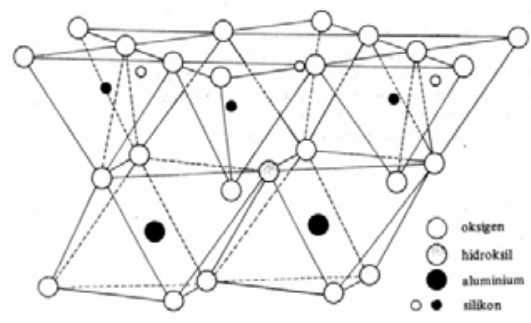

\section{Gambar 1. Struktur Atom dari Kaolinite (Grim, 1959)}

Rumus kimianya adalah :

$$
\mathrm{Al}_{2} \mathrm{O}_{3}: \mathrm{SiO}_{2}: \mathrm{H}_{2} \mathrm{O}=1: 2: 2 \text {, atau } 2 \mathrm{SiO}_{2} \cdot \mathrm{Al}_{2} \mathrm{O}_{3} \cdot 2 \mathrm{H}_{2} \mathrm{O} \text { per unit sel. }
$$




\section{Montmorrilonite,}

Merupakan tanah yang sangat ekspansif karena ikatan antar lapisannya disebabkan oleh gaya Vander Wall yang lebih lemah dari ikatan hidrogen atau ikatan ion lainnya. Montmorillonite mempunyai struktur yang sama dengan Illite, yaitu terdiri dari dua lembaran silika dan satu lembaran aluminium atau gibbsite (Gambar 2.). Pada montmorillonite terjadi substitusi isomorfis antara atom-atom magnesium dan besi menggantikan sebagian atom-atom ion kalium seperti pada illite, dan sejumlah besar molekul tertarik pada ruangan antara lapisan-lapisan tersebut. Kristal montmorillonite sangat kecil tetapi mempunyai gaya tarik yang cukup terhadap air. Tanah yang mengandung mineral ini sangat mudah mengembang oleh tambahan kadar air. Rumus kimia montmorrilonite sebagai berikut:

$$
\mathrm{Al}_{2} \mathrm{O}_{3} \cdot 4 \mathrm{SiO}_{2} \cdot \mathrm{H}_{2} \mathrm{O}+\mathrm{x} \mathrm{H} \mathrm{H}_{2} \mathrm{O}
$$

Jadi dapat dijelaskan besarnya swelling ditentukan oleh mineral yang ada dalam tanah lempung, dan tanah lempung yang banyak mengandung montmorillonite akan lebih besar pengembangannya daripada tanah yang banyak mengandung koalinite. Juga dapat disimpulkan bahwa besarnya swelling ditentukan oleh kimia tanahnya (banyaknya kation-kation dalam tanah). Kation terutama yang memiliki valensi yang tinggi berfungsi sebagai pengikat antar partikel-partikel lempung dan mengurangi pengembangan atau pembesaran jarak antar partikel. Jadi kembang susut tanah dapat dikurangi dengan cara menambah kation-kation dalam tanah, seperti $\mathrm{Na}^{+}, \mathrm{K}^{+}, \mathrm{Ca}^{+}, \mathrm{Mg}^{++}$dll.

Lempung expansive merupakan jenis tanah lempung yang di klasifikasikan kedalam jenis tanah kurang baik yang memiliki nilai pengembangan dan nilai penyusutan yang besar, pengembangan (swelling) adalah pembesaran volume tanah ekspansif akibat bertambahnya kadar air, Sedangkan penyusutan (shrinkage) adalah pengecilan volume tanah ekspansif akibat berkurangnya kadar air.

Potensi kembang susut yang besar ini dapat menimbulkan kerusakan pada struktur yang berada diatasnya. Hal tersebut disebabkan karena besarnya nilai aktivitas (A) tanah lempung, besar kecilnya nilai aktivitas tanah lempung dipengaruhi oleh nilai indeks plastisitas (IP) tanah, pada Tabel 2.3 "Potensi Pengembangan" (Holzt, 1954: Gibbs, 1954: USBR, 1974) dapat diketahui potensi pengembangan suatu jenis tanah berdasarkan nilai indeks plastisitasnya (IP), untuk tanah lempung yang dapat dikategorikan kedalam tanah lempung yang expansive yakni tanah yang memiliki potensi pengembangan yang sangat tinggi batasan nilai indeks plastisitasnya (IP) $>35 \%$, selain itu nilai aktivitas tanah lempung juga dapat dipengaruhi oleh jenis mineral yang terkandung pada tanah tersebut semakin plastis mineral lempung semakin potensial untuk menyusut dan mengembang (Tabel 3).

Tanah-tanah yang banyak mengandung lempung mengalami perubahan volume atau mengalami pengembangan atau penyusutan ketika kadar air berubah, perubahan itulah yang membahayakan bangunan, maka dari itu air berfungsi sebagai penentu sifat plastisitas dari lempung.

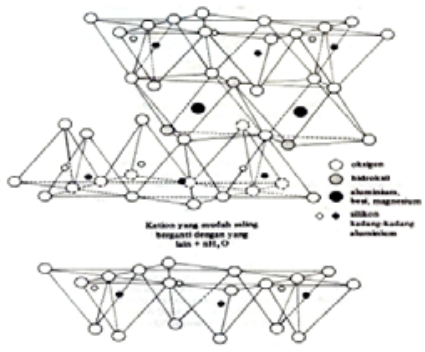

Gambar 2. Struktur Atom dari Montmorillonite (Grim, 1959). 
Tabel 3. Potensi Pengembangan (Holzt, 1954: Gibbs, 1954: USBR, 1974)

\begin{tabular}{|c|c|c|c|c|c|}
\hline $\begin{array}{c}\text { Potensi } \\
\text { pengembangan }\end{array}$ & $\begin{array}{c}\text { Pengembangan(\%) } \\
\text { (akibat tekanan } \\
6,9 \mathrm{KPa})\end{array}$ & $\begin{array}{c}\text { Persen } \\
\text { koloid } \\
(<0,001 \mathrm{~mm}) \\
(\%)\end{array}$ & $\begin{array}{c}\text { Indek } \\
\text { plastisitas } \\
\text { PI (\%) }\end{array}$ & $\begin{array}{c}\text { Batas } \\
\text { susut SL } \\
(\%)\end{array}$ & $\begin{array}{c}\text { Batas } \\
\text { cair } \\
\text { LL } \\
(\%)\end{array}$ \\
\hline Sangat tinggi & $>30$ & $>28$ & $>35$ & $>11$ & $>65$ \\
\hline Tinggi & $20-30$ & $20-31$ & $25-41$ & $7-12$ & $50-63$ \\
\hline Sedang & $10-20$ & $13-23$ & $15-28$ & $10-16$ & $39-50$ \\
\hline Rendah & $<10$ & $<15$ & $<18$ & $<15$ & 39 \\
\hline
\end{tabular}

3. Illite

memiliki formasi struktur satuan kristal yang hampir sama dengan montmorrilonite. Satu satuan kristal illite memiliki tebal dan komposisi yang sama dengan montmorrilonite. Perbedaannya adalah:

- Terdapat kurang lebih dua puluh persen pergantian silicon (Si) oleh aluminum (Al) pada lempeng tetrahedral.

- Antar satuan kristal terdapat kalium (K) yang berfungsi sebagai penyeimbang muatan dan pengikat antar satuan kristal.

- Struktur mineralnya tidak mengenbang sebagaimana montmorrilonite.

Illite merupakan kelompok Mica-like, termasuk illites dan vermiculites, bisa berperilaku ekspansif tetapi umumnya tidak menimbulkan persoalan yang berarti. Illite terdiri dari sebuah lembaran oktahedra yang terikat dua lembaran silika tetrahedra. Dalam lembaran oktahedra, terdapat substitusi parsial aluminium oleh magnesium dan besi serta di dalam lembaran tetrahedra terdapat pula substitusi silikon oleh aluminium yang menghasilkan muatan negatif. Muatan negatif ini mengikat ion kalium yang terdapat diantara lapisan-lapisan illite. Ikatan-ikatan tersebut lebih lemah dari pada ikatan hidrogen pada kristal kaolinite, tetapi lebih kuat dari ikatan ionik yang membentuk kristal montmorillonite. Rumus kimianya adalah :

$$
\mathrm{H}_{2} \mathrm{KAl}_{3} \mathrm{O}_{12} \longrightarrow \mathrm{Al}_{2} \mathrm{O}_{3} 4 \mathrm{SiO}_{2} \mathrm{H}_{2} \mathrm{O}+x \mathrm{H}_{2} \mathrm{O}
$$

\subsection{Semen}

Semen adalah material yang mempunyai sifat-sifat adhesif dan kohesif sebagai perekat yang mengikat fragmen-fragmen mineral menjadi suatu kesatuan yang kompak. Semen dikelompokan ke dalam 2 (dua) jenis yaitu semen hidrolis dan semen non-hidrolis.

Semen hidrolis adalah suatu bahan pengikat yang mengeras jika bereaksi dengan air serta menghasilkan produk yang tahan air. Contohnya seperti semen portland, semen putih dan sebagainya, sedangkan semen non-hidrolis adalah semen yang tidak dapat stabil dalam air.

Semen Portland adalah semen hidrolis yang dihasilkan dengan cara mencampurkan batu kapur yang mengandung kapur $(\mathrm{CaO})$ dan lempung yang mengandung silika $(\mathrm{SiO} 2)$, oksida alumina (Al2O3) dan oksida besi ( $\mathrm{Fe} 2 \mathrm{O} 3)$ dalam oven dengan suhu kira-kira $145^{\circ} \mathrm{C}$ sampai menjadi 
klinker. Klinker ini dipindahkan, digiling sampai halus disertai penambahan 3-5\% gips untuk mengendalikan waktu pengikat semen agar tidak berlangsung terlalu cepat (Aman Subakti,1994).

Dalam semen Portland ini terdapat susunan senyawa semen yang berfungsi sebagai berikut:

1. $\mathrm{C} 3 \mathrm{~S}=3 \mathrm{CaO} . \mathrm{SiO} 2$ (Trikalsium Silikat) mempunyai andil yang besar terhadap fungsi sebagai perekat dan dapat mengeras jika bereaksi dengan air sehingga dapat meningkatkan kekuatan tekan

2. $\mathrm{C} 2 \mathrm{~S}=2 \mathrm{CaO} . \mathrm{SiO} 2$ (Dikalsium Silikat) berfungsi sama dengan $\mathrm{C} 3 \mathrm{~S}$

3. $\mathrm{C} 3 \mathrm{~A}=3 \mathrm{CaO} \cdot \mathrm{A} 12 \mathrm{O} 3$ (Trikalsium Aluminat) dalam semen portland tidak berfungsi sebagai perekat. Senyawa ini hanya berfungsi sebagai fluks (bahan pelebur) sewaktu masih ada dalam tungku pembakaran, sehingga akan mudah terbentuk senyawa $\mathrm{C} 3 \mathrm{~S}$ dan $\mathrm{C} 2 \mathrm{~S}$

4. $\mathrm{C} 4 \mathrm{AF}=4 \mathrm{CaO} \cdot \mathrm{Al} 2 \mathrm{O} 3 . \mathrm{Fe} 2 \mathrm{O} 3$ (Tetra Alumineferrit) berfungsi sama seperti C3A serta andil terhadap warna semen.

5. Gips $=\mathrm{CaSO} 4.2 \mathrm{H} 2 \mathrm{O}$ berfungsi sebagai retarder atau memperlambat waktu pengerasan tepung semen portland bila bercampur dengan air.

6. Selain itu terdapat komposisi kimia lain seperti : $\mathrm{C}=\mathrm{CaO}, \mathrm{Na} 2 \mathrm{O}, \mathrm{K} 2 \mathrm{O}$ dalam jumlah yang kecil

\subsection{Pengujian Kepadatan Tanah (Proctor Standar)}

Pemadatan adalah suatu proses memadatnya partikel tanah sehingga terjadi pengurangan volume udara dan volume air dengan memakai cara mekanis. Di lapangan, usaha pemadatan dihubungkan dengan jumlah gilasan dari mesin gilas, atau hal lain yang prinsipnya sama untuk suatu volume tanah tertentu. Di laboratorium, pemadatan didapat dari tumbukan. Selama pemadatan palu dijatuhkan dari ketinggian tertentu beberapa kali pada beberapa lapisan tanah dalam suatu cetakan.

Beberapa keuntungan yang didapatkan dengan adanya pemadatan ini adalah :

a. Memperkecil pengaruh air terhadap tanah.

b. Bertambahnya kekuatan tanah.

c. Mengurangi perubahan volume sebagai akibat perubahan kadar air (Hardiyatmo, H.C., 1992, hal 53)

d. Memperkecilkan pemampatan dan daya rembes air.

\subsection{Pengujian CBR (California Bearing Ratio)}

CBR (California Bearing Ratio) adalah suatu perbandingan antara beban percobaan (test load) dengan beban standar (standard load) dan dinyatakan dalam persentase.

Ada dua macam pengukuran CBR yaitu :

1. Nilai CBR untuk tekanan penetrasi pada $0.254 \mathrm{~cm}(0,1$ ") terhadap penetrasi stándar besarnya $70,37 \mathrm{~kg} / \mathrm{cm} 2(1000 \mathrm{psi})$.

$$
\mathrm{CBR}=\frac{P 1}{70,37} \times 100 \% \quad\left(\mathrm{P}_{1} \text { dalam } \mathrm{kg} / \mathrm{cm}^{2}\right)
$$

2. Nilai CBR untuk tekanan penetrasi pada penetrasi $0,508 \mathrm{~cm}(0,2)$ terhadap penetrasi standard yang besarnya $105,56 \mathrm{~kg} / \mathrm{cm} 2(1500 \mathrm{psi})$

3.

$$
\mathrm{CBR}=\frac{P 2}{105.56} \times 100 \% \quad\left(\mathrm{P}_{2} \text { dalam } \mathrm{kg} / \mathrm{cm}^{2}\right)
$$




\subsection{Stabilisasi Tanah}

Menurut Bowles (1986), stabilitas dapat terdiri dari salah satu tindakan sebagai berikut:

1. menambah kerapatan tanah.

2. menambah material yang tidak aktif sehingga mempertinggi kohesi atau tahanan geser.

3. menambah material untuk menyebabkan perubahan-perubahan kimiawi dan fisik dari material tanah.

4. menurunkan muka air tanah (dewatering), dan

5. mengganti tanah-tanah yang buruk.

\section{Stabilisasi Tanah dengan Semen}

Kezdi (1979) melaporkan bahwa dengan menambah semen baik kedalam tanah lempung maupun kedalam tanah pasir akan meningkatkan kepadatan maksimum tanah tersebut sebesar kurang lebih $10 \%$. Namun demikian, jika diterapkan pada tanah lanau kepadatannya justru menurun. Menurutnya, semen menurunkan indeks plastisitas tanah kohesif yang disebabkan oleh peningkatan batas plastis serta penurunan batas cairnya.

Hasil penelitian menunjukkan bahwa nilai CBR, dan kepadatan standar naik dengan naikknya presentase semen didalam tanah. Kadar optimum tercapai pada kadar semen 7,5\%. Pada kadar semen tersebut terlihat adanya penurunan potensi pengembangan dan peningkatan nilai CBR yang cukup signifikan. Pada pengujian tekan bebas terlihat bahwa semaikin tinggi kadar semen, nilai parameter kuat geser tanah semakin naik. Dalam hal ini tidak terlihat adanya kadar semen optimum

\section{HASIL PENELITIAN DAN ANALISA}

\subsection{Hasil Pengujian}

\subsubsection{Hasil Uji Sifat Fisik dan Mekanik Tanah Asli}

Hasil Pengujian sifat fisik dan mekanik tanah asli dapat dilihat pada Tabel 4.

Tabel 4. Hasil Pengujian Sifat Fisik dan Mekanik Tanah Lempung Lambung Bukik

\begin{tabular}{|c|l|c|}
\hline No & \multicolumn{1}{|c|}{ Pengujian } & Hasil \\
\hline 1 & Kadar air $(\%)$ & 58.121 \\
\hline 2 & Berat Volume $\left(\mathrm{gr} / \mathrm{cm}^{3}\right)$ & 1.831 \\
\hline 3 & Berat Jenis & 2.587 \\
\hline 4 & Batas Cair $(\%)$ & 82.843 \\
\hline 5 & Batas Plastis (\%) & 56.291 \\
\hline 6 & Indeks Plastisitas (\%) & 26.553 \\
\hline 7 & OMC $(\%)$ & 37.50 \\
\hline 8 & $\%$ Lolos Saringan 200 & 96.733 \\
\hline 9 & $\gamma_{\text {dry }}$ maks $\left(\mathrm{gr} / \mathrm{cm}^{3}\right)$ & 1.23 \\
\hline 10 & CBR $(\%)$ & 8.204 \\
\hline
\end{tabular}




\subsubsection{Hasil Uji Sifat fisik dan mekanik campuran tanah Lempung dan Portland C}

Hasil uji sifat fisik dan mekanik campuran tanah lempung dan portland $\mathrm{C}$ untuk kadar semen $5 \%$, 10\%, 15\%, dan 20\% dapat dilihat pada Tabel 5-8

Tabel 5. Hasil Pengujian Sifat Fisik Tanah Lempung Lambung Bukik $+5 \%$ Semen

\begin{tabular}{|c|l|c|}
\hline No & \multicolumn{1}{|c|}{ Pengujian } & Hasil \\
\hline 1 & Berat Jenis & 2.590 \\
\hline 2 & Batas Cair (\%) & 70.789 \\
\hline 3 & Batas Plastis (\%) & 61.356 \\
\hline 4 & Indeks Plastisitas (\%) & 9.433 \\
\hline 5 & OMC $(\%)$ & 36.65 \\
\hline 6 & $\gamma_{\text {dry }}$ maks $\left(\mathrm{gr} / \mathrm{cm}^{3}\right)$ & 1.262 \\
\hline 7 & CBR 3 hari $(\%)$ & 24.611 \\
\hline
\end{tabular}

Tabel 6. Hasil Pengujian Sifat Fisik Tanah Lempung Lambung Bukit $+10 \%$ Semen

\begin{tabular}{|c|l|c|}
\hline No & \multicolumn{1}{|c|}{ Pengujian } & Hasil \\
\hline 1 & Berat Jenis & 2.604 \\
\hline 2 & Batas Cair (\%) & 64.964 \\
\hline 3 & Batas Plastis (\%) & 60.225 \\
\hline 4 & Indeks Plastisitas (\%) & 4.577 \\
\hline 5 & OMC (\%) & 34.98 \\
\hline 6 & $\gamma_{\text {dry }}$ maks $\left(\mathrm{gr} / \mathrm{cm}^{3}\right)$ & 1.291 \\
\hline 7 & CBR 3 hari $(\%)$ & 43.256 \\
\hline
\end{tabular}

Tabel 7. Hasil Pengujian Sifat Fisik Tanah Lempung Lambung Bukit + 15\% Semen

\begin{tabular}{|c|l|c|}
\hline No & \multicolumn{1}{|c|}{ Pengujian } & Hasil \\
\hline 1 & Berat Jenis & 2.604 \\
\hline 2 & Batas Cair (\%) & 64.964 \\
\hline 3 & Batas Plastis (\%) & 60.225 \\
\hline 4 & Indeks Plastisitas (\%) & 4.577 \\
\hline 5 & OMC (\%) & 34.98 \\
\hline 6 & $\gamma_{\text {dry }}$ maks $\left(\mathrm{gr} / \mathrm{cm}^{3}\right)$ & 1.291 \\
\hline 7 & CBR 3 hari $(\%)$ & 43.256 \\
\hline
\end{tabular}

Tabel 8. Hasil Pengujian Sifat Fisik Tanah Lempung Lambung Bukit $+20 \%$ Semen

\begin{tabular}{|c|l|c|}
\hline No & \multicolumn{1}{|c|}{ Pengujian } & Hasil \\
\hline 1 & Berat Jenis & 2.604 \\
\hline 2 & Batas Cair (\%) & 64.964 \\
\hline 3 & Batas Plastis (\%) & 60.225 \\
\hline 4 & Indeks Plastisitas (\%) & 4.577 \\
\hline 5 & OMC (\%) & 34.98 \\
\hline 6 & $\gamma_{\text {dry }}$ maks $\left(\mathrm{gr} / \mathrm{cm}^{3}\right)$ & 1.291 \\
\hline 7 & CBR 3 hari $(\%)$ & 43.256 \\
\hline
\end{tabular}




\subsection{Analisa}

\subsubsection{Analisa Sifat Fisik Tanah Asli}

Berdasarkan data hasil pengujian dapat diklasifikasikan sifat tanah berdarkan atas beberapa sistem yang ada yaitu :

1. Sistem klasifikasi USCS

2. Sistem klasifikasi AASHTO

1. Sistem klasifikasi USCS

Sistem klasifikasi ini paling banyak diaplikasikan pada pengujian tanah. Sistem klasifikasi USCS merupakan sistem pengelompokan berbasis hasil-hasil percobaan laboratorium. Adapun hasil dari pengujian Laboratorium menunjukkan data propertis tanah yang diperolah adalah :

1. Tanah yang lolos saringan no. $200=96,733 \%$.

2. $\quad$ Batas Cair (LL) $=82,843 \%$

3. Indeks Plastisitas (IP) $=26,533 \%$

Dari data propertis tanah yang diperoleh diatas maka dapat disimpulkan beberapa hal, yaitu :

a. Berdasarkan nilai prosentase lolos saringan no. 200 tanah lempung di atas, prosentase tersebut lebih besar dari $50 \%$, maka berdasarkan tabel klasifikasi USCS tanah ini secara umum dikategorikan golongan tanah berbutir halus.

b. Dari Tabel sistem klasifikasi USCS Untuk data batas cair dan indeks plastisitas diplotkan pada diagram plastisitas sehingga didapatkan identifikasi tanah yang lebih spesifik. Hasil dapat dilihat pada Gambar 5.1.

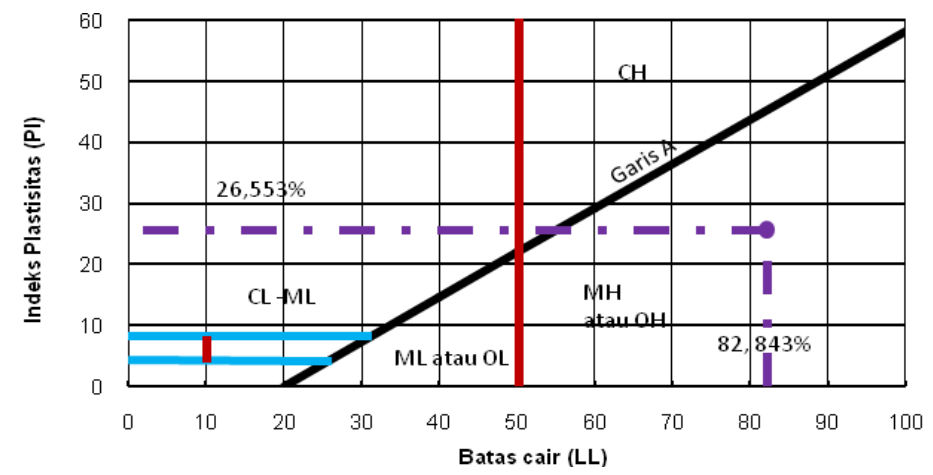

Gambar 3. Diagram Plastisitas Tanah Berbutir Halus USCS ( Braja M. Das, 1985)

Dapat dilihat pada Gambar 3. bahwa hasil pengeplotan menunjukkan satu titik pertemuan pengeplotan di bawah garis A, yang mana titik temu ini menjelaskan jenis tanah yang diuji. Dengan merujuk pada hasil di atas maka tanah berbutir halus Lambung Bukit yang diuji termasuk kedalam kelompok $\mathrm{OH}$ yaitu tanah lempung organik dengan plastisitas sedang sampai tinggi dengan nilai Indeks Plastisitas sebesar 26,553 \% (plastisitas tinggi).

2. Sistem klasifikasi AASHTO

Berdasarkan pada tabel klasifikasi tanah AASHTO dan propertis tanah, dimana presentase lolos saringan nomor 200 lebih besar dari $35 \%$, sehingga dapat disimpulkan secara umum tanah masuk kelompok lanau-lempung. Dengan diketahuinya nilai batas cair (LL) lebih besar dari $41 \%$, dan harga indeks Plastisitas (PI) lebih besar dari $11 \%$ tetapi lebih kecil daripada harga batas cair (LL) dikurangi 30, maka tanah termasuk golongan A-7-5. 
Untuk mendapatkan pengelompokan yang lebih detail maka dihitung indeks kelompoknya dengan persamaan yang terdapat pada Gambar 4:

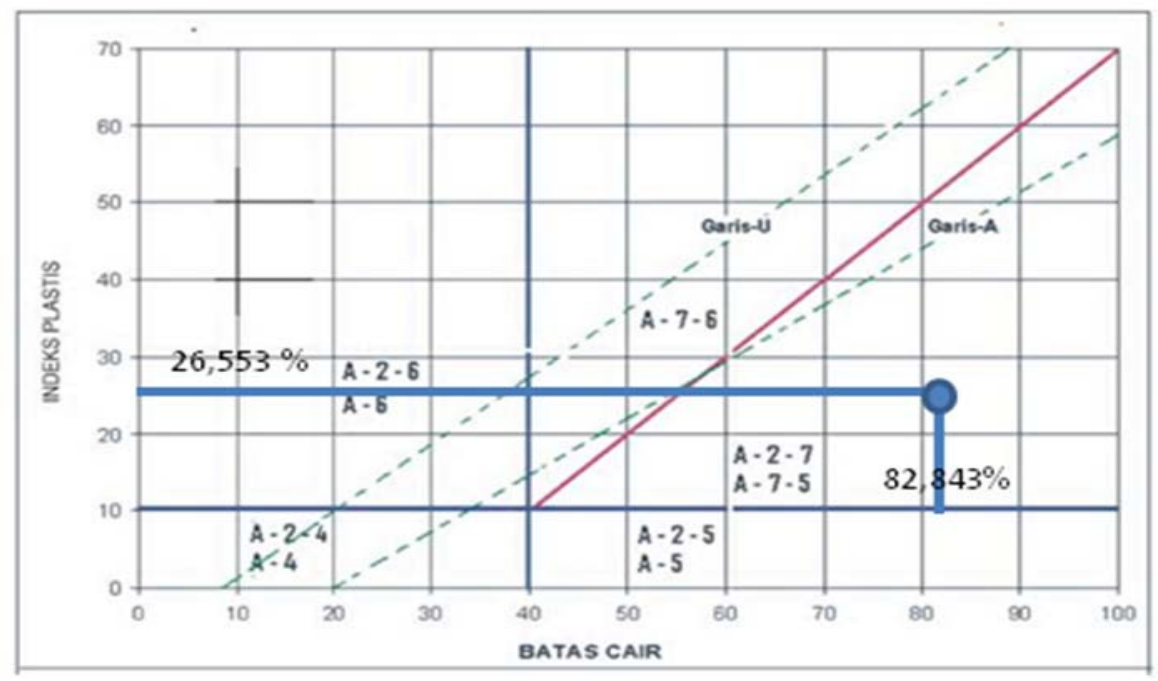

Gambar 4. Nilai - Nilai Batas Atterberg Untuk Subkelompok A-4, A-5, A-6, dan A-7 (Braja M. Das, 1985)

Berdasarkan sistem klasifikasi AASHTO maka tanah lempung yang berasal dari daerah Lambung Bukit, Kecamatan Pauh, Padang dapat dikategorikan ke dalam kelompok tanah berlempung A-75(39).

Untuk hasil pemeriksaan berat jenis dan batas konsistensi tanah dapat dilihat pada Tabel $\mathbf{3 . 1}$ Berdasarkan batasan berat jenis untuk beberapa jenis tanah yang dikemukakan Hary Christady Hardiyatmo (2002), tanah tersebut dapat dikatakan sebagai tanah lempung organik, karena memiliki berat jenis 2.587 . Hal ini mungkin disebabkan karena tanah banyak mengandung bahanbahan organik yang massanya lebih ringan daripada massa tanah, sehingga menyebabkan nilai berat jenisnya menjadi rendah.

Sedangkan untuk nilai batas konsistensi tanah, berdasarkan Tabel 2. (Hubungan antara Indeks Plastisitas dan Jenis Tanah) tanah tersebut memiliki plastisitas tinggi, karena nilai indeks plastisitasnya sebesar $26.553 \%$ dengan jenis tanah lempung. Itu artinya tanah tersebut peka terhadap air disekitarnya, kemungkinan pengembangan (swelling) dapat terjadi pada tanah ini.

\subsubsection{Perbandingan Sifat Fisik dan Mekanik Tanah Lempung Dengan Campuran Portland Cement Type I}

Berikut ini adalah Tabel 9 dan Gambar 5 yang menunjukkan pengaruh sifat fisik dan mekanik tanah lempung dengan Portland Cement Type I.

\subsubsection{Hasil Uji Berat Jenis}

Pada pengujian berat jenis tanah lempung dengan campuran semen dapat terlihat bahwa nilai berat jenis semakin basar seperti yang terlihat pada Gambar 5. 
Tabel 9. Hasil Pengujian Berat Jenis Tanah Lempung dengan Campuran Semen

\begin{tabular}{|c|c|c|}
\hline No & $\begin{array}{c}\text { Kadar Semen } \\
(\%)\end{array}$ & $\begin{array}{c}\text { Berat Jenis } \\
\left(\mathrm{gr} / \mathrm{cm}^{3}\right)\end{array}$ \\
\hline 1 & 0 & 2.587 \\
\hline 2 & 5 & 2.590 \\
\hline 3 & 10 & 2.604 \\
\hline 4 & 15 & 2.613 \\
\hline 5 & 20 & 2.642 \\
\hline
\end{tabular}

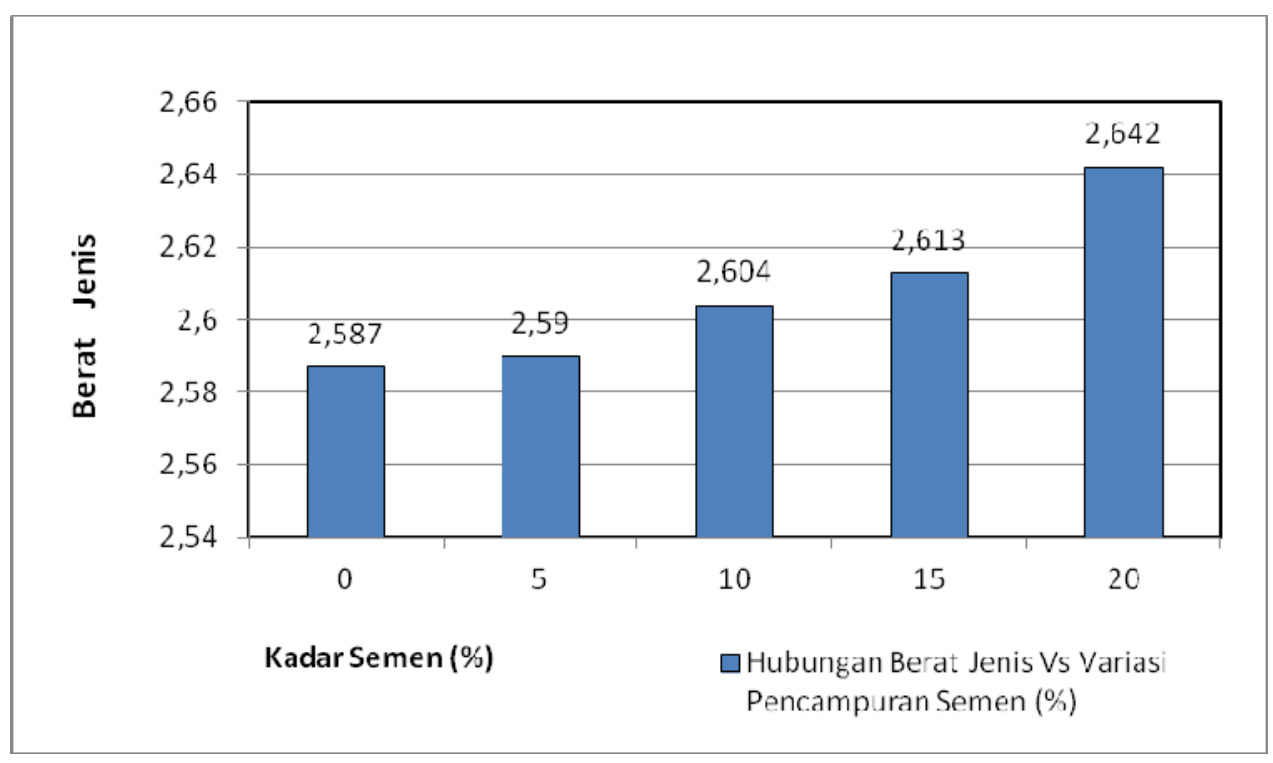

Gambar 5. Pengaruh Penambahan Portland Cement Type I Terhadap Berat Spesifik (GS)

Dari gambar diatas dapat dilihat seiring bertambahnya semen, tanah lempung mengalami kenaikan berat jenis campuran. Dapat kita lihat berat jenis sebelum penambahan semen didapat 2,587 \% dan setelah penambahan $5 \%$ semen, berat jenis meningkat menjadi $5,9 \%$ sampai penambahan $20 \%$ semen berat jenis meningkat menjadi $2,642 \%$.

Hal ini disebabkan karena Semen yang bercampur dengan tanah mengakibatkan terjadinya proses pertukaran kation alkali $(\mathrm{Na}+$ dan $\mathrm{K}+$ ) dari tanah digantikan oleh kation dari semen sehingga ukuran butiran lempung bertambah besar (flokulasi). Bertambahnya ukuran butiran ini akan mengakibatkan mikropori dan makropori yang ada pada tanah lempung meningkat seiring dengan bertambahnya kadar bahan stabilisasi.

Menurut Kezdi (1790), proses sementasi pada tanah akan menyebabkan penggumpalan yang merekat antar partikel, rongga-rongga pori yang ada sebagian akan dikelilingi bahan sementasi yang lebih keras dan lebih sulit untuk ditembur air.

Oleh karena itu penambahan semen pada tanah lempung akan menyebabkan air sulit masuk ke mikropori dan makropori tanah lempung, sehingga penambahan semen akan menyebabkan berat jenis tanah lempung meningkat. 


\subsubsection{Hasil Uji Atterberg Limit}

Hasil pengujian Atterberg Test tanah lempung dengan campuran portland cement type I dapat dilihat pada Tabel 10, sedangkan pengaruh penambahan Portland Cement Type I terhadap nilai nilai batas cair (LL), batas plastis (PL) dan indeks plastisitas (IP) dapat dilihat pada Gambar 6.

Tabel 10. Hasil Pengujian Atterberg Test Tanah Lempung Dengan Campuran Portland Cement Type I

\begin{tabular}{|c|c|c|c|c|}
\hline No & $\begin{array}{c}\text { Kadar } \\
\text { Semen } \\
(\mathbf{\%})\end{array}$ & $\begin{array}{c}\text { LL } \\
\mathbf{( \% )}\end{array}$ & $\begin{array}{c}\text { PL } \\
\mathbf{( \% )}\end{array}$ & $\begin{array}{c}\text { IP } \\
\mathbf{( \% )}\end{array}$ \\
\hline 1 & 0 & 82.843 & 56.291 & 26.553 \\
\hline 2 & 5 & 70.798 & 61.356 & 9.433 \\
\hline 3 & 10 & 64.964 & 60.255 & 4.577 \\
\hline 4 & 15 & 64.623 & 59.225 & 5.398 \\
\hline 5 & 20 & 73.266 & 59.644 & 13.622 \\
\hline
\end{tabular}

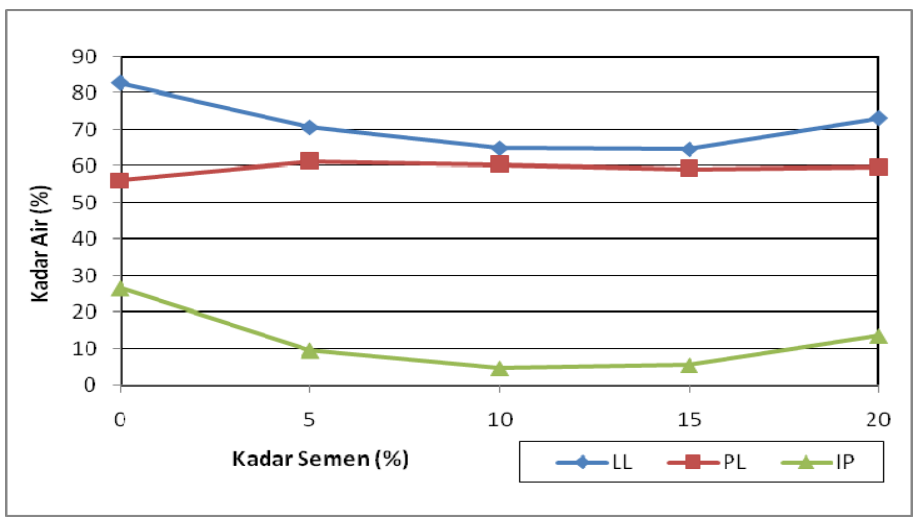

\section{Gambar 6. Pengaruh Penambahan Portland Cement Type I Terhadap Nilai Nilai Batas Cair} (LL), Batas Plastis (PL) Dan Indeks Plastisitas (IP)

Hasil penelitian batas-batas konsistensi setelah penambahan semen adalah sebagai berikut. Terlihat bahwa semakin tinggi kadar semen batas plastis meningkat dan batas cair menurun, sehingga indeks plastisitas (IP) tanah menurun.

Fenomena tersebut menunjukkan terjadinya pertukaran ion-ion $\mathrm{K}+$ (potassium) dan $\mathrm{Na}+$ (sodium) yang terkandung dalam tanah lempung oleh ion-ion $\mathrm{Ca}^{++}$dan $\mathrm{Mg}^{++}$yang terkandung didalam semen. Pertukaran kation pada partikel-partikel lempung membuat ukuran partikel menjadi bertambah besar dan mengurangi indeks plastisitas tanah yang kemudian diikuti oleh penurunan potensi pengembangan tanah. Penambahan semen juga akan meningkatkan derajat keasaman $(\mathrm{pH})$ tanah yang berakibat pada peningkatan kapasitas pertukaran ion-ion positif (kation).

Selain itu, silica $\left(\mathrm{SiO}_{2}\right)$, dan alumina $\left(\mathrm{Al}_{2} \mathrm{O}_{3}\right)$ dari semen bercampur dengan air membentuk pasta yang mengikat partikel lempung dan menutupi pori-pori tanah. Rongga-rongga pori yang dikelilingi bahan sementasi yang lebih sulit ditembus air akan membuat campuran tanah-semen lebih tahan terhadap penyerapan air sehingga menurunkan sifat plastisitasnya. 


\subsubsection{Hasil Uji Atterberg Limit}

Hasil pengujian pemadatan tanah lempung dapat dilihat pada Tabel 11.

Tabel 11. Hasil pengujian pemadatan tanah lempung dengan campuran Portland Cement Type I

\begin{tabular}{|c|c|c|c|}
\hline No & $\begin{array}{c}\text { Kadar } \\
\text { Semen (\%) }\end{array}$ & $\begin{array}{c}\text { Wopt } \\
\mathbf{( \% )}\end{array}$ & $\begin{array}{c}\gamma d r y \\
\mathbf{( g r} / \mathbf{m l})\end{array}$ \\
\hline 1 & 0 & 37.5 & 1.23 \\
\hline 2 & 5 & 36.65 & 1.262 \\
\hline 3 & 10 & 34.98 & 1.291 \\
\hline 4 & 15 & 34 & 1.319 \\
\hline 5 & 20 & 32.9 & 1.35 \\
\hline
\end{tabular}

Pada Gambar 7 dan 8 menunjukkan bahwa pemberian semen sebagai bahan campuran dapat menurunkan kadar air optimum dan meningkatkan berat volume kering tanah dari kondisi sebelum distabilisasi. Terlihat bahwa kenaikan meningkat seiring bertambahnya semen. Kepadatan maksimum terbesar terjadi pada penambahan kadar semen sebesar $20 \%$ yaitu $1.35 \mathrm{gr} / \mathrm{cm}^{3}$

Hal ini disebabkan semen mengisi rongga pori tanah, yang pada kondisi tanah asli, rongga pori tersebut terisi oleh air dan udara. Akibat adanya semen dalam rongga pori tanah ini, prosentase air yang dikandung tanah menjadi berkurang. Peningkatan jumlah partikel padat pada tanah berdampak pada peningkatan berat volume keringnya dibandingkan pada kondisi tanah asli.

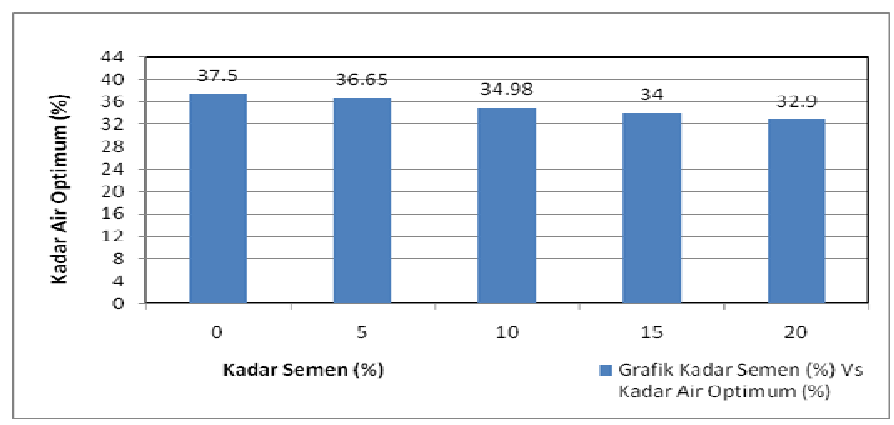

Gambar 7. Grafik Pengaruh Penambahan Portland Cement Type I Terhadap Kadar Air Optimum (W Opt)

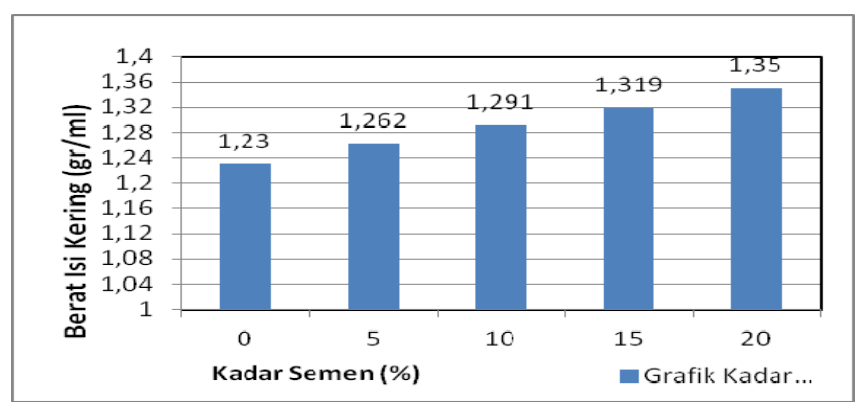

Gambar 8. Grafik Pengaruh Penambahan Portland Cement Type I Terhadap Terhadap Berat Isi Kering ( $\Gamma \mathrm{d})$ 
Selain itu meningkatnya kepadatan maksimum ini disebabkan karena terjadinya reaksi posolanik yang semakin meningkat karena unsur-unsur $\mathrm{SiO}_{2}, \mathrm{Al}_{2} \mathrm{O}_{3}$, dan $\mathrm{Fe}_{2} \mathrm{O}_{3}$ yang bertambah oleh semen. Proses pozzolan terjadi antara kalsium hidroksida dari tanah bereaksi dengan silikat $\left(\mathrm{SiO}_{2}\right)$ dan aluminat $\left(\mathrm{AlO}_{3}\right)$ dari semen membentuk material pengikat yang terdiri dari kalsium silikat atau aluminat silikat. Reaksi dari ion $\mathrm{Ca}_{2}{ }^{+}$dengan silikat $\left(\mathrm{SiO}_{2}\right)$, dan aluminat $\left(\mathrm{Al}_{2} \mathrm{O}_{3}\right)$ dari permukaan partikel lempung membentuk pasta semen (hydrated gel) sehingga mengikat partikel-partikel tanah

\subsubsection{Hasil Uji CBR (California Baring Ratio)}

Hasil dari pengujian CBR tanah lempung dengan campuran Portland Cement Type I dapat dilihat pada Tabel 12. Sementara dari Gambar 9 dapat dilihat bahwa seiring penambahan semen telah meningkatkan nilai daya dukung tanah daerah Lambung Bukit pada pemeraman 3 hari secara signifikan. Reaksi sementasi yang terjadi pada campuran tanah-semen membentuk butiran baru yang lebih keras sehingga lebih kuat menahan beban yang diberikan.

Semen yang bercampur dengan tanah mengakibatkan terjadinya proses pertukaran kation alkali $\left(\mathrm{Na}^{+}\right.$dan $\left.\mathrm{K}^{+}\right)$dari tanah digantikan oleh kation dari semen sehingga ukuran butiran lempung bertambah besar (flokulasi). Selain proses flokulasi yang terjadi dalam stabilisasi tanah, terjadi pula proses pozzolan, proses hidrasi, dan proses sementasi.

Proses pozzolan terjadi antara kalsium hidroksida dari tanah bereaksi dengan silikat $\left(\mathrm{SiO}_{2}\right)$ dan aluminat $\left(\mathrm{AlO}_{3}\right)$ dari semen membentuk material pengikat yang terdiri dari kalsium silikat atau aluminat silikat. Reaksi dari ion $\mathrm{Ca}_{2}{ }^{+}$dengan silikat dan aluminat dari permukaan partikel lempung membentuk pasta semen (hydrated gel) sehingga mengikat partikel-partikel tanah. Proses sementasi dapat juga terjadi karena sifat semen bila bercampur dengan air yang sesuai akan menjadi pozzolan / sementasi.

Mekanisme terjadinya setting dan hardening (pengikatan dan pengerasan) yaitu ketika terjadi pencampuran dengan air, maka akan terjadi air dengan $\mathrm{C}_{3} \mathrm{~A}$ membentuk $3 \mathrm{CaO} \cdot \mathrm{Al}_{2} \mathrm{O}_{3} \cdot 3 \mathrm{H}_{2} \mathrm{O}$ yang bersifat kaku dan berbentuk gel.

\section{Tabel 12. Hasil pengujian CBR tanah lempung dengan campuran Portland Cement Type I}

\begin{tabular}{|c|c|c|}
\hline No & $\begin{array}{c}\text { Kadar Semen } \\
(\%)\end{array}$ & $\begin{array}{c}\text { CBR 3 Hari } \\
(\%)\end{array}$ \\
\hline 1 & 0 & 8.204 \\
\hline 2 & 5 & 24.611 \\
\hline 3 & 10 & 43.256 \\
\hline 4 & 15 & 55.934 \\
\hline 5 & 20 & 64.138 \\
\hline
\end{tabular}

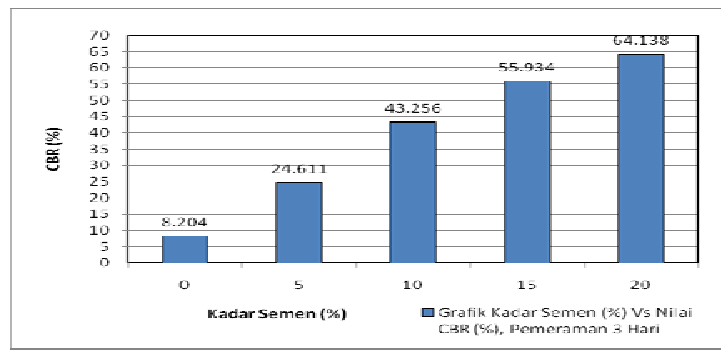

Gambar 10. Grafik Pengaruh Penambahan Portland Cement Type I Terhadap Nilai CBR Dengan Pemeraman 3 Hari. 


\section{KESIMPULAN}

Bedasarkan hasil penelitian yang telah dilakukan, dapat diambil kesimpulan sebagai berikut :

1. Menurut USCS, tanah daerah Lambung Bukit termasuk dalam kelas $\mathrm{OH}$ yaitu tanah lempung organik dengan plastisitas sedang sampai tinggi, sedangkan menurut AASHTO tanah ini termasuk tanah berlempung dengan penilaian sedang sampai buruk. Dengan batas cair yang lebih besar dari $41 \%$. Jadi tanah daerah Lambung Bukit dapat dikategorikan sebagai tanah berlempung. Sehingga dikategorikan buruk dan perlu distabilisasi.

2. Sifat plastis tanah akan menurun dengan diberikan bahan aditif semen. Penurunan indeks plastisitas tanah dimana IP tanah asli $26,553 \%$ bila dicampur dengan $10 \%$ kadar semen IP menjadi $4,577 \%$. Penurunan nilai PI tersebut dapat mengurangi potensi pengembangan dan penyusutan tanah.

3. Dari hasil uji pemadatan dengan proctor standar diperoleh nilai $\gamma_{\mathrm{dr}}$ maks $=1.23 \mathrm{gr} / \mathrm{cm}^{3}$ dan kadar air optimum sebesar 37,5\%. Penambahan semen dengan variasi penambahan sebesar $5 \%, 10 \%, 15 \%$, dan $20 \%$ yang mengisi rongga pori tanah telah meningkatkan $\gamma_{\text {dr }}$ maks masing-masing menjadi $1,262 \mathrm{~g} / \mathrm{cm}^{3}, 1,291 \mathrm{~g} / \mathrm{cm}^{3}, 1,319 \mathrm{~g} / \mathrm{cm}^{3}$ dan $1,35 \mathrm{~g} / \mathrm{cm}^{3}$ dan kadar air optimum sebesar $36.65 \%, 34.98 \%, 34 \%, 32.9 \%$.

4. Penambahan semen telah meningkatkan nilai daya dukung tanah secara signifikan. Nilai CBR semakin naik seiring dengan penambahan semen, dimana nilai CBR tanah asli sebesar $8.204 \%$. Terjadinya peningkatan nilai CBR pada campuran optimum $20 \%$ semen dengan waktu pemeraman 3 hari dengan nilai CBR 64,138\%.

\section{DAFTAR KEPUSTAKAAN}

Bowless J. E, (1991), "Sifat-sifat Fisis Dan Geoteknis Tanah”, Alih Bahasa Johan Kelanaputra Hainim, Erlangga.

Chen, F.H., (1976), "Fondation in Expansive Soil", Elvesier Scienttific Publishning Company, New York.

Craig, R.F, (1989), “Mekanika Tanah”, Erlangga, Jakarta

Das, Braja M, (1995), “Mekanika Tanah, Jilid 2”, Erlangga, Jakarta.

Das, Braja M, (1985), “Mekanika Tanah, Jilid 1”, Erlangga, Jakarta.

Grim. RE., "Bentonites, Geology, Minerology, Properties and Uses", Elsevier Scientific Publishing Company, Amsterdam, Oxford, New

Hary Christady Hardiyatmo, (1992), "Mekanika Tanah I", Penerbit Universitas Gadjah Mada, Yogyakarta.

Hary Christady Hardiyatmo, (1996), "Mekanika Tanah I", Penerbit Universitas Gadjah Mada, Yogyakarta.

Hary Christady Hardiyatmo, (2002), “Teknik Pondasi I edisi kedua”, Penerbit Universitas Gadjah Mada, Yogyakarta.

Holtz, W.G. \& Gibbs, Hj., (1954), “Engineering Properties of Expansive Clays”, Prog. ASCE, Soil Mechanic Foundation Div. 80 (516).

Kezdi, A., (1979), "Stabilization Earth Roads", Elvesier Scientific Publishing Company, New York. 
Pengaruh Penggunaan Semen Sebagai Bahan Stabilisasi Pada Tanah Lempung Daerah Lambung Bukit Terhadap Nilai CBR Tanah

44 | J URNAL REKAYASA SIPIL 